\title{
PENGARUH LEADERSHIP STYLE DAN ORGANIZATIONAL CULTURE TERHADAP PRODUCTIVITY OF EMPLOYEE DI KOPERASI SIMPAN PINJAM- SEJAHTERA BERSAMA (KSP-SB) CABANG SUKABUMI
}

\author{
Umban Adi Jaya \\ Program Studi Manajemen, Institut Manajemen Wiyata Indonesia \\ umbanadijaya01@gmail.ac.id \\ Ai Kartini \\ Program Studi Manajemen, Institut Manajemen Wiyata Indonesia \\ Aikartini98@gmail.com
}

\begin{abstract}
This research was conducted at the Sukabumi Branch of the Savings and Loans Cooperative and the Prosperous Cooperative (KSP-SB) with a full address on Jl. R.E Martadinata No. 62 B Cikole Village, Cikole District, Sukabumi City- (0266) 211867, This study runs from January 2018 to completion.The purpose of this study was to determine the effect of leadership style (X1) and organizational culture (X2) on productivity of employee (Y). The types and sources of data used in this study consisted of primary data and secondary data with a total sample of 30 people. Sampling is done using population sampling method. Technical quality testing tools include testing validity and reliability, classical assumptions, and data analysis techniques using descriptive and correlation analysis. Whereas to determine the effect of independent variables $(X)$ on the dependent variable $(Y)$, multiple linear regression analysis was used which included the t test and F test with the help of SPSS version 16.0. Based on the results of the partial test ( $t$ test), it can be seen that the leadership style variable has a positive but not significant effect on productivity of employee, while the organizational culture variable has a positive and significant influence on productivity of employee. Based on the results of the Simultaneous Test (Test F) it is known that the variables of leadership style and organizational culture together have a significant influence on productivity of employee at the Sukabumi Branch of the Joint Savings and Loan Cooperative $(K S P-S B)$.
\end{abstract}

Keywords: leadership style; organizational culture and productivity of employee

\section{Pendahuluan}

Perekonomian di Indonesia saat ini mengalami perkembangan. Lembaga Keuangan menjadi salah satu yang memberikan kontribusi tinggi dalam perkembangan ekonomi. Perbankan menjadi tujuan utama untuk memudahkan masyarakat bertransaksi, tetapi tidak hanya bank yang menjadi Financial Intermediary. Di Indonesia mempunyai lembaga keuangan selain bank yang menjadi ciri khas untuk bertransaksi yaitu koperasi. jumlah koperasi di Indonesia terus meningkat dan mengalami perkembangan yang cukup signifikan dari tahun ke tahun. Pertumbuhan koperasi yang tinggi akan berkontribusi terhadap perekonomian negara, terutama dalam penyerapan tenaga kerja dan pembayaran retribusi termasuk pajak unit usaha koperasi. Tahun 2010, jumlah koperasi di Indonesia sebanyak kurang lebih 177.492unit dan sekitar 29,55\% koperasi yang tidak aktif. Total koperasi di Indonesia mulai berkembang pesat pada per desember 2015 yaitu sebanyak 212. 135 unit. Jumlah ini mencatatkan Indonesia sebagai negara dengan jumlah koperasi terbesar di dunia. Jumlah total koperasi tersebut terbagi atas 
150.223unit koperasi aktif dan 61.912unit koperasi tidak aktif (dalam laporan statistiknya, Kemenkop menyebut angka ini sangat sementara). Koperasi sebanyak itu tersebar di 34 provinsi dengan jumlah keseluruhan anggota mencapai 37,78 juta orang. Pada tahun 2016, kontribusi anggota koperasi terhadap PDB Nasional sebesar $20.71 \%$ (Adinata, 2015).

Pada dasarnya koperasi bukan bertujuan untuk mendapatkan keuntungan badan koperasi itu sendiri ataupun untuk individu, tetapi tujuan koperasi adalah menyimpan uang masyarakat dengan rasa aman, selain itu masyarakat juga dapat melakukan peminjaman kepada pihak koperasi dengan bunga yang kecil untuk melakukan usaha yang diinginkan dan memenuhi kebutuhan hidupnya, inilah alasan mengapa koperasi memegang peranan penting dalam pertumbuhan ekonomi masyarakat Indonesia dan untuk mensejahterakan bersama. Maka dari itu, pencapaian visi dan misi dibutuhkan pengelola manajerial yang baik. Produktivitas kerja menjadi salah satu hal penting dalam perusahaan untuk menopang target yang dibutuhkan di setiap perusahaan. Produktivitas dalam organisasi pada dasarnya berpusat pada sumber daya manusia yang dimiliki oleh organisasi (Adinata, 2015).

Koperasi Simpan Pinjam-Sejahtera Bersama Cabang Sukabumi menjadi salah satu cabang dari Koperasi Simpan PinjamSejahtera Bersama yang berdiri pada tahun 2006, sedangkan kantor pusat Koperasi Simpan Pinjam-Sejahtera Bersama berlokasi di Bogor-Jawa Barat yang didirikan pada bulan januari 2004 (Laporan Tahunan Dana Anggota Simpanan Untuk Remunerasi Tahun 2014 - 2017, 2017). Koperasi Simpan Pinjam Sejahtera Bersama (KSP-
SB) dalam mengembangkan usahanya, terkadang mengalami penurunan productivity dalam mencapai target organisasi. hal ini dapat dilihat dari data laporan tahunan dana anggota simpanan untuk remunerasi tahun 2014-2017 dibawah ini:

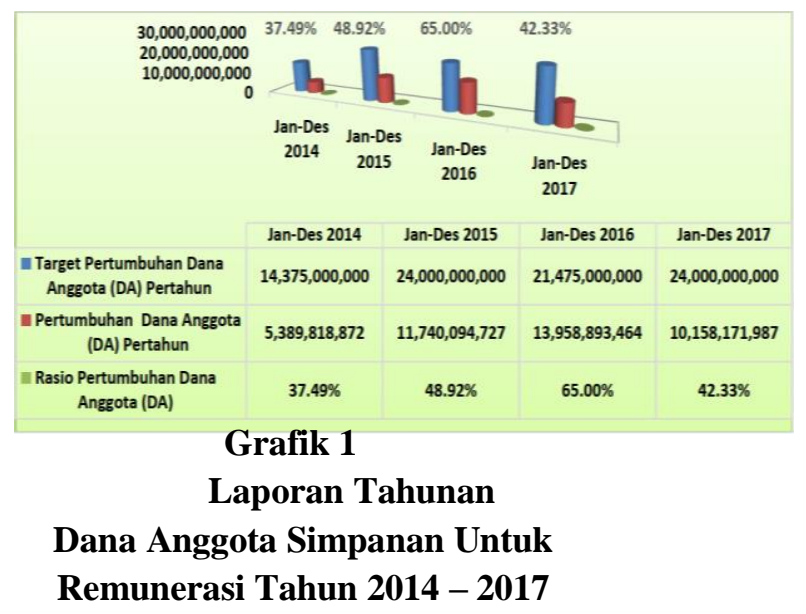

Data yang diperoleh dari grafik di atas menunjukkan adanya penurunan dalam mencapai target yang sudah ditentukan oleh koperasi, hal tersebut terlihat dari jumlah pertumbuhan dana anggota untuk remunerasi tahun 2014-2017. Data tersebut merupakan penurunan productivity of employee di setiap tahunnya (Laporan Tahunan Dana Anggota Simpanan Untuk Remunerasi Tahun 2014 - 2017, 2017). Dengan demikian, dapat disimpulkan bahwa productivity of employee di Koperasi Simpan Pinjam- Sejahtera Bersama (KSPSB) Cabang Sukabumi mengalami penurunan, hal tersebut disebabkan karena adanya penurunan kualitas SDM dan menyebabkan tidak tercapai target yang telah ditentukan selama beberapa tahun tersebut. Tidak tercapainya target dari tahun 2014-2017. Productivity of employee di KSP-SB menurun karena didominasi oleh faktor internal yang menyangkut rendahnya kualitas SDM yang diduga karena 
dipengaruhi oleh adanya penerapan sistem leadership style yang belum tepat dan kurangnya pengarahan dari leadership, dimana leadership style yang diterapkan belum mampu mendorong karyawan untuk bisa mencapai productivity of employee yang baik. Selain leadership style, terdapat juga organizational culture, para karyawan KSP-SB belum bisa menerapkan nilai dan norma-norma dengan baik. Masalah tersebut mengakibatkan penurunan productivity pada Koperasi Simpan Pinjam-Sejahtera Bersama (KSP-SB) Cabang Sukabumi.

Berdasarkan fenomena dan masalah di atas, maka dilakukan penelitian dengan judul: "Pengaruh Leadership Style dan Organizational Culture terhadap Productivity of Employee di Koperasi Simpan Pinjam-Sejahtera Bersama (KSPSB) Cabang Sukabumi',

\section{Tinjauan Pustaka}

\section{Manajemen}

Dalam kamus umum Bahasa Indonesia manajemen merupakan cara mengelola suatu perusahaan besar. Pengelolaan tersebut dilaksanakan oleh seorang manajer atau pemimpin berdasarkan urutan dan ketentuan manajemen (Adinata, 2015). Namun dari masa ke masa, banyak para ahli yang memandang dari beberapa sudut untuk mendefinisikan manajemen, antara lain:

a. Manajemen Sebagai Ilmu dan Seni, merupakan pengetahuan dari hasil pengamatan dan diorganisasikan secara sistematis dan diaplikasikan dengan daya penyesuaian sebagai keahlian, kemahiran, dan keterampilan yang dapat dipakai dalam kehidupan manusia.

$\begin{array}{lrr}\text { b. } \begin{array}{l}\text { Manajemen } \\ \text { merupakan }\end{array} & \begin{array}{r}\text { Sebagai } \\ \text { proses }\end{array} & \text { Proses, } \\ & \text { untuk }\end{array}$

perencanaan, pengorganisasian, dan penggerakkan organisasi lainnya yang bertujuan untuk mencapai tujuan perusahaan.

c. Manajemen Sebagai

Profesi, merupakan tuntutan untuk menjadi kompeherensif agar setiap anggota individu atau kelompok dapat menjalankan tugasnya dengan baik.

\section{Manajemen Sumber Daya Manusia}

Manajemen sumber daya manusia adalah suatu bidang manajemen yang khusus mempelajari hubungan dan peranan manausia dalam organisasi perusahaan. Seperti yang dijelaskan oleh (Hasibuan, 2013) bahwa manajemen sumber daya manusia adalah ilmu dan seni untuk mengatur hubungan dan peranan tenaga kerja agar efektif dan efesien dalam membantu terwujudnya tujuan perusahaan, karyawan dan masyarakat. Pernyataan tersebut setara dengan pernyataan American Society of Mechanical Engineer (Tim Dosen Adpen UPI) dalam (Badrudin, 2013) bahwa manajemen merupakan ilmu dan seni mengorganisasi dan memimpin usaha manusia, menerapkan pengawasan dan pengendalian tenaga, serta memanfaatkan bahan alam bagi kebutuhan manusia. (Badrudin, 2013) menekankan bahwa manajemen sumber daya manusia adalah manfaat individu untuk mencapai tujuan organisasi.

\section{Leadership Style}

Kepemimpinan dalam suatu organisasi merupakan suatu peran penting yang menentukan atas berhasil tidaknya suatu organisasi atau usaha, sebab kepemimpinan yang sukses menunjukan bahwa pengelolaan suatu organisasi berhasil dilaksanakan dengan sukses. Leadership Style seorang pemimpin 
dalam memimpin sebuah organisasi atau perusahaan sangatlah penting untuk menunjang kinerja pegawai dalam perusahaan. Adanya Leadership Style yang efektif tersebut diharapkan dapat membuat motivasi pegawai meningkat yang mengakibatkan pencapaian visi dan misi yang maksimal (Kartono, 2017).

Blanchard (1996) mengatakan bahwa Leadership Style merupakan perilaku kerja dan perilaku hubungan yang harus diterapkan terhadap derajat kesiapan maupun kematangan tertentu (Blanchard, 1996).

\section{Leadership Style tersebut akan} sangat efektif apabila dapat mengakomodasi lingkungannya (pengikut, atasan dan rekan kerjanya). (Blanchard, 1996), menyatakan bahwa Leadership Style merupakan pola pendekatan yang ditunjukkan oleh seorang pemimpin. Pendapat senada disampaikan oleh Newstrom dan Davis (2002) bahwa Leadership Style adalah gaya total dari tindakan ekplisit dan implisit yang dilihat oleh pegawainya. Pemimpin dalam kepemimpinannya perlu memikirkan dan memperlihatkan Leadership Style yang akan diterapkan kepada pegawainya.

\section{Leadership Style menurut} (Handoko, 2014) merupakan faktor penting dari perusahaan sebab dalam kenyataannya pemimpin dapat mempengaruhi moral, kualitas kehidupan kerja, dan terutama tingkat prestasi suatu organisasi. Sedangkan menurut (Thoha, 2007) Leadership Style adalah suatu pola perilaku yang konsisten yang kita tunjukkan dan diketahui oleh pihak lain ketika kita berusaha memengaruhi kegiatan-kegiatan orang lain. Masingmasing gaya tersebut memiliki keunggulan dan kelemahan. Seorang pemimpin akan menggunakan Leadership Style sesuai kemampuan dan kepribadiannya.

\section{Faktor-faktor yang mempengaruhi leadership}

Faktor-faktor yang mempengaruhi Leadership Style menurut (Handoko, 2014) yaitu: 1) pemimpin, 2) pengikut, dan 3) situasi, ketiganya saling berhubungan dan berinteraksi satu dengan yang lainnya. Menurut Mangkunegara, yang mempengaruhi Leadership Style faktornya adalah sebagai berikut (Mangkunegara, 2013):

a. Intergritas: kejujuran dan kelugasan.

b. Kompetensi: pengetahuan dan keterampilan.

c. Konsistensi: keandalan, kemampuan, diramalkan dan penilaian yang baik.

d. Loyalitas: kesediaan untuk melindungi.

e. Keterbukaan: kerelaan untuk berbagi ide dan informasi.

\section{Dimensi Leadership Style}

(Blanchard, 1996) mengemukakan bahwa terdapat 4 dimensi dalam leadership style, diantaranya:

a. Gaya Mengarahkan (Telling Style) pada situasi ini, seorang pemimpin memberi arahan kepada bawahannya untuk mengerjakan sesuatu atau pada saat bawahan tersebut merasa kesulitan untuk mengerjakan pekerjaanya, maka seorang pemimpin

mengarahkan/memerintahkan apa yang harus dilakukan para bawahan.

b. Gaya menawarkan (Selling Style) dalam situasi ini, pemimpin menunjukkan hubungan tinggi dari segi penyelesaian masalah dan hubungan dengan orang bawahan 
adalah rapat sebagai satu organisasi. seorang pemimpin juga berperan aktif sebagai konsultan dalam organisasi, hal tersebut bertujuan untuk membantu para karyawannya dan mempererat hubungan antara pemimpin dan bawahan.

c. Gaya Partipasi (Participating Style) dalam situasi ini, pemimpin juga harus memberikan motivasi / mendorong karyawan dengan tujuan meningkatkan percaya diri yang mereka miliki bahwa mereka mampu melaksanakan tugasnya.

d. Gaya Delegasi (Delegating Style) pada situasi ini karyawan memiliki kompetensi dan juga komitmen yang tinggi untuk menyelesaikan tugas sehingga pemimpin dapat melakukan pendelegasian pekerjaan kepada para bawahan. Akibatnya para pemimpin dalam situasi ini memiliki fokus terhadap pekerjaan dan hubungan kerja yang rendah dengan bawahannya.

\section{Organizational Culture}

Organizational culture ialah sebagai sebuah sistem makna bersama yang dianut oleh para anggota yang membedakan organisasi tersebut dengan organisasi lainnya. Selain itu, Robbins and judge (2012) menggambarkan, bahwa organizational culture adalah sebagai tradisi dan cara umum dalam melakukan sesuatu yang telah dilakukan sebelumnya dan seberapa akan sukses dalam melakukannya dengan sumber utama berasal dari pendiri yang memiliki visi dalam organisasi (Robbins, 2012). Teori lain memberikan pemahaman bahwa organizational culture harus dikaitkan dengan perilaku organisasi. Menurut Sweeney \& McFarlin (2002), perilaku organisasi berkaitan dengan ' 'bagaimanan dan mengapa orang- orang bertindak, berpikir, dan merasa dalam suatu organisasi', Organizational Culture sering diartikan sebagai nilainilai, simbol-simbol yang dipahami dan dipatuhi bersama dalam suatu organisasi, sehingga anggota organisasi tersebut dapat merasakan yang berbeda dengan organisasi lainnya (Sweeney, P.D., dan McFarlin, 2002). Sedangkan menurut Wirawan (2011) menjelaskan dengan lengkap bahwa Organizational Culture merupakan norma, nilai-nilai, asumsi, kepercayaan, filsafat, kebiasaan organisasi, dan sebagainya yang dikembangkan dalam waktu yang lama oleh pendiri, pemimpin, dan anggota organisasi yang disosialisasikan dan diajarkan kepada anggota baru serta diterapkan dalam aktivitas organisasi sehingga berpengaruh pada pola pikir, sikap, dan perilaku anggota organisasi dalam memproduksi produk, melayani para konsumen, dan mencapai tujuan organisasi (Wirawan, 2011).

Berdasarkan penyataan tersebut dapat disimpulkan bahwa Organizational Culture merupakan nilai dan norma yang dianut dan dipercayai oleh para karyawan di dalam organisasi untuk melakukan sesuatu dengan cara-cara tertentu sehingga akan terdapat hasil yang diharapkan sesuai keinginan dalam suatu oganisasi. Selain itu, dengan adanya organizational culture yang baik, terdapat asumsi atau sistem keyakinan yang dikembangkan oleh organisasi sehingga dapat mengatasi masalahmasalah pada organisasi tersebut. 
7. Dimensi Organizational Culture

Robbins dan Judge

mengemukakan pendapat bahwa Organizational Culture memiliki 3 (tiga) dimensi, diantaranya yaitu:

a. Innovation and Courage to take risks (inovasi dan keberanian mengambil resiko), Inovasi adalah suatu gagasan baru yang ditetapkan untuk memprakarsai atau memperbaiki suatu produk, proses atau jasa. Melalui inovasi dapat diketahui seberapa jauh anggota organisasi didorong untuk menemukan caracara baru yang lebih baik, tingkat kreativitas, dorongan untuk melakukan terobosan-terobosan baru dalam bekerja dan dorongan untuk mengembangkan kemampuan.

b. Team Orientation (berorientasi kepada tim), Bagaimana unit-unit di dalam organisasi didorong melakukan kegiatannya dalam suatu koordinasi yang baik. Seberapa jauh keterkaitan dan kerja-sama ditekankan dalam pelaksanaan tugas dan seberapa dalam interdependensi antar anggota ditanamkan.

c. Aggressiveness (agresifitas)

Sejauhmana orang-orang itu agresif dan kompetitif dan bukannya santaisantai dalam penyelesaian pekerjaan dan persaingan kerja(Robbins, 2012).

\section{Productivity of Employee}

Nasution (2004) mengatakan
bahwa pada dasarnya dalam ilmu
ekonomi, productivity merupakan nisbah
atau rasio antara hasil kegiatan (output,
keluaran) dan segala pengorbanan (biaya)
untuk mewujudkan hasil tersebut (input,
masukan) (Nasution, 2004). Konsep
productivity dikembangkan untuk
mengukur besarnya kemampuan

menghasilkan nilai tambah atas komponen masukan yang digunakan. Menurut Sutrisno (2016), productivity of employee adalah sikap mental dan kemampuan menghasilkan barang dan jasa dari berbagai sumber daya yang bertujuan untuk meningkatkan kualitas dan kuantitas pekerjaan yang dihasilkan dengan cara mengukur perbandingan antara hasil yang dicapai (input) dengan keseluruhan sumberdaya yang digunakan (output) (Rahmawati, 2016).

\section{Dimensi Productivity of Employee}

Adapun dimensi productivity of employee menurut ada 6 (enam) yaitu sebagai berikut:

a. Kemampuan: Seorang karyawan harus memiliki kemampuan

untuk melaksanakan tugas. Kemampuan tersebut bergantung pada keterampilan masing-masing karyawan. Kemampuan akan memberikan kekuatan untuk menyelesaikan setiap tugas yang dikerjakannya.

b. Meningkatkan hasil yang dicapainya: Setiap karyawan wajib untuk meningkatkan hasil. Hasil tersebut akan dituai dan dirasakan oleh karyawan yang telah berhasil meningkatkan produktivitas diperusahaan meraka.

c. Semangat kerja; Semangat kerja merupakan usaha untuk meningkatkan hasil dari yang sebelumnya. Dimensi ini dapat dilihat dari etos kerja karyawan.

d. Pengembangan diri: dapat dilakukan dengan melihat tantangan atau harapan dan cara menghadapinya. Semakin kuat tantangan, maka pengembangan harus mutlak dilakukan. Harapan untuk menjadi 
lebih baik akan berdampak pada keinginan karyawan untuk meningkatkan kemampuan.

e. Mutu: Mutu merupakan hasil pekerjaan yang dapat menunjukkan hasil kualitas kerja seorang karyawan. Meningkatkan mutu bertujuan untuk memberikan hasil yang lebih baik dan akan berguna bagi perusahaan atau dirinya sendiri.

f. Efisiensi: Efisiensi merupakan perbandingan antara hasil yang dicapai dengan keseluruhan sumber daya yang digunakan. Input dan output merupakan aspek productivity yang memberikan pengaruh yang cukup signifikan bagi karyawan.

\section{Penelitian Terdahulu}

Penelitian terdahulu yang menunjukkan bahwa Leadership Style dan Organizational Culture berpengaruh positif signifikan terhadap Productivity of Employee diperoleh dari hasil penelitian (Setiawan, 2010) yang berjudul 'Pengaruh Gaya Kepemimpinan Dan Budaya Organisasi Terhadap Produktivitas Kerja Pegawai Dinas Olah Raga Dan Pemuda Provinsi Jawa Barat'.

Menurut (Luhat, 2017) yang berjudul "Pengaruh Gaya Kepemimpinan Dan Komunikasi Terhadap Produktivitas Kerja Karyawan Pada Pt. Gunta Samba Jaya Miau Baru Estate Di Desa Miau Baru', (Latief, 2015) yang berjudul 'Pengaruh Gaya Kepemimpinan Dan Motivasi Terhadap Produktivitas Kerja Karyawan Pada Afdeling Prapen I Kebun Unit 1 PT Mopoli Raya Kabupaten Langkat”. (Zebua, 2017)'Pengaruh Gaya Kepemimpinan Terhadap Produktivitas Kerja Karyawan Pada PT. Coca-Cola Cabang Malang'. (Ongi, 2015) yang berjudul " Pengaruh
Budaya Organisasi Dan Motivasi Kerja Terhadap Produktivitas Karyawan Pada PT. Nusa Halmahera Minerals Di Kab. Halmahera Utara'. I Gusti Agung Aries Indrajaya dan (Indrajaya;, 2013) yang berjudul Pengaruh Budaya Organisasi, Komunikasi Dan Lingkungan Kerja Terhadap Produktivitas Kerja Karyawan Cv. Hitakara Denpasar', (Goren, 2018) yang berjudul 'Effect of Leadership Styles on Employee Productivity at South Nyanza Sugar Company Limited, Migori County'. (Ahiabor, 2014) yang berjudul 'The Impact Of Corporate Culture On Productivity of Firms In Ghana: A Case Of Vodafone Ghana'.

\section{Model Analis}

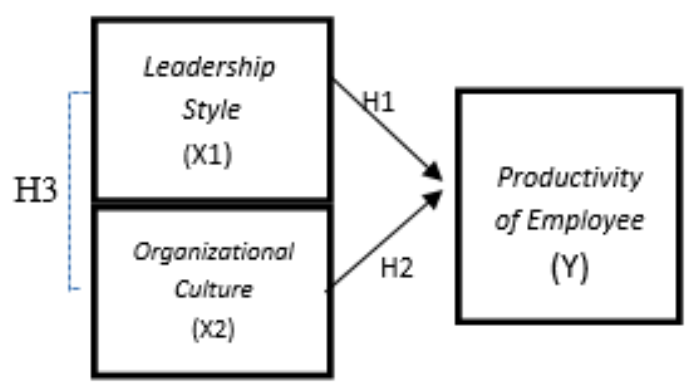

Gambar 1

Model Analisis

Sumber: Hasil Olah Data (2018)

Hipotesis Kerja/Alternatif (Ha)

Ha-1 = Terdapat pengaruh yang positif dan signifikan antara Leadership Style terhadap productivity of employee di Koperasi Simpan Pinjam- Sejahtera Bersama (KSP-SB) Cabang Sukabumi

Ha-2 = Terdapat pengaruh yang positif dan signifikan antara Organizational Culture terhadap Productivity of Employee di Koperasi Simpan Pinjam-Sejahtera Bersama (KSP-SB) Cabang Sukabumi

Ha-3 = Terdapat pengaruh yang positif dan signifikan antara Leadership Style dan Organizational Culture terhadap Productivity of Employee di Koperasi 
Simpan Pinjam- Sejahtera Bersama (KSPSB) Cabang Sukabumi.

\section{Metode Penelitian}

\section{Tempat dan Waktu Penelitian}

Tempat penelitian yang dipilih oleh penulis untuk melakukan penelitiannya yaitu pada Koperasi Simpan Pinjam Sejahtera Bersama (KSP-SB) yang beralamatkan di Jl. RE. Martadinata Sukabumi. Pengambilan penelitian dilaksanakan pada bulan Januari 2018Agustus 2018.

\section{Populasi dan Sampel}

Populasi yang terdapat di KSP-SB Cabang Sukabumi yaitu sebanyak 30 orang karyawan. Arikunto (2013) mengemukakan bahwa jika populasi kurang dari 100 (seratus) orang, lebih baik semua populasi tersebut diambil untuk dijadikan sampel sehingga penelitiannya merupakan penelitian populasi (Arikunto, 2013). Jumlah karyawan yang terdapat di KSP-SB Cabang Sukabumi kurang dari 100, maka yang akan menjadi sampel adalah seluruh karyawan di KSP-SB Cabang Sukabumi, yaitu 30 orang karyawan.

\section{Penentuan dan Pengumpulan Data}

Penentuan dan Pengumpulan Data data yang digunakan dalam penelitian ini adalah melalui data primer yaitu melalui observasi, wawancara, studi dokumentasi dan secara langsung melakukan penyebaran kuesioner (angket) kepada seluruh karyawan KSP-SB di Kota Sukabumi, sedangkan data sekunder yang digunakan oleh penulis diperoleh dari hasil studi kepustakaaan yang meliputi buku-buku dan data lain yang relevan dengan wilayah penelitian.

\section{Metode Analisis Data}

Metode analisis data yang digunakan dalam penelitian ini yaitu metode deskriptif kuantitatif, Skala Likert. Alat analisis data yang digunakan dalam penelitian ini adalah SPSS (Software Statistical Package of Science) 16 for Windows Version.

\section{Hasil Penelitian Dan Pembahasan}

\section{A. Hasil Penelitian}

Penelitian ini telah dilakukan di Koperasi Simpan Pinjam-Sejahtera

Bersama (KSP-SB) Cabang Sukabumi dengan jumlah responden sebanyak 30 orang. Peneliti memperoleh gambaran tentang profil responden yang dideskripsikan berdasarkan jenis kelamin, usia, pendidikan terakhir, lama bekrja, dan pendapatan dapat dilihat pada tabel 1

\begin{tabular}{|c|c|c|cc|}
\hline \multicolumn{2}{|c|}{ Kategori Responden } & $\begin{array}{c}\text { Jumlah } \\
\text { Orang }\end{array}$ & \multicolumn{2}{|c|}{$\begin{array}{c}\text { Presentase } \\
(\%)\end{array}$} \\
\hline Usia & $18-22$ & 0 & 0.0 & $\%$ \\
\hline & $22-27$ & 2 & 5.7 & $\%$ \\
\hline & $27-32$ & 9 & 25.7 & $\%$ \\
\hline & $>32$ & 24 & 68.6 & $\%$ \\
\hline $\begin{array}{c}\text { Jenis } \\
\text { Kelamin }\end{array}$ & Laki-Laki & 21 & 60.0 & $\%$ \\
\hline & Perempuan & 14 & 40.0 & $\%$ \\
\hline $\begin{array}{c}\text { Pendidikan } \\
\text { Terakhir }\end{array}$ & SD & 0 & 0.0 & $\%$ \\
\hline & SMP & 0 & 0.0 & $\%$ \\
\hline & SMA & 15 & 42.9 & $\%$ \\
\hline & Lainnya & 20 & 57.1 & $\%$ \\
\hline $\begin{array}{c}\text { Lama } \\
\text { Bekerja }\end{array}$ & $3-6$ Bulan & 1 & 2.9 & $\%$ \\
\hline & $1-3$ Tahun & 5 & 14.3 & $\%$ \\
\hline & $3-5$ Tahun & 9 & 25.7 & $\%$ \\
\hline & $>5$ Tahun & 20 & 57.1 & $\%$ \\
\hline Pendapatan & $<$ Rp 1.000.000 & 1 & 2.9 & $\%$ \\
\hline & Rp 1.100.000 - Rp 2.000.000 & 8 & 22.9 & $\%$ \\
\hline & Rp 2.100.000 - Rp 3.000.000 & 4 & 11.4 & $\%$ \\
\hline & $>$ Rp 3.000.000 & 22 & 62.9 & $\%$ \\
\hline
\end{tabular}

Hasil olah data berdasarkan kategori jenis kelamin responden yang ada di KSP- SB Cabang Sukabumi menunjukkan bahwa jumlah karyawan laki-laki yang bekerja di sana lebih banyak dibandingkan dengan jumlah karyawan perempuan yaitu sebanyak $60 \%$ Dengan demikian, 
mengindikasikan bahwa tingginya tingkat kuantitas laki-laki yang mendominasi bekerja di KSP-SB Cabang Sukabumi. Hasil olah data berdasarkan kategori usia responden menunjukkan bahwa di KSP-SB Cabang Sukabumi memiliki sumber daya manusia yang produktif dan mempunyai semangat yang tinggi dalam bekerja. Banyaknya para karyawan yang sudah berusia lebih dari 32 tahun yang bekerja di KSP-SB (sebanyak $76,7 \%$ ), maka mereka lebih banyak mengetahui dan mengerti dengan lebih baik tentang tugas dan kewajibannya sebagai seorang karyawan. Hasil olah data berdasarkan kategori tingkat pendidikan dilihat dari latar belakang para pegawai yang bekerja di KSP-SB Cabang Sukabumi menunjukkan bahwa sebanyak $36,7 \%$ para pegawai mempunyai latar belakang tingkat pendidikan di atas SMA/SMK (lulusan S1, Akademika, dll) dan sebanyak 63,3\% berpendidikan SMA/SMK. Hasil olah data berdasarkan kategori lamanya bekerja menunjukkan bahwa banyaknya responden yang sudah bekerja di KSPSB yang mendominasi yaitu karyawan yang sudah lebih dari lima tahun bekerja dengan jumlah sebanyak 57\%, 26\% untuk lama bekerja dari 3-5 tahun, 14\% dari 1-3 tahun dan 3\% untuk lama bekerja dari 3-6 bulan. Karakteristik responden yang mendominasi lamanya bekerja menunjukkan bahwa mereka telah memiliki pengalaman kerja yang lama dan lebih paham mengenai pekerjaannya dengan baik. Hasil olah data berdasarkan kategori pendapatan menunjukkanbahwa banyaknya responden yang sudah bekerja di KSPSB yang mendominasi yaitu yang mempunyai pendapatan dengan jumlah sebanyak 66,7\%, 20,0\% Rp. 2.100.000Rp.3.000.000, 13,3\% Rp.1.100.000 Rp. 2.000 .000 dan $0,0 \%$ untuk pendapatan di bawah Rp. 1.000.000.

\section{Pengujian Instrumen Uji Validitas}

Arikunto (2013) mengatakan bahwa validitas merupakan suatu ukuran yang menujukkan tingkat kevalidan atau kesahihan suatu instrumen. Hasil pengujian validitas menyatakan bahwa untuk variabel leadership style, organizational culture, dan productivity of employee dengan seluruh item pernyataan yang ada yang dijadikan sebagai indikator menunjukkan bahwa semua indikator valid mampu mengukur 3 (tiga) variabel tersebut (Arikunto, 2013). Kesimpulan ini ditarik dari hasil perbandingan $r$ hitung masingmasing item dengan $r$ tabel yang menunjukkan adanya nilai yang lebih besar di hasil $r$ hitung semua item, $r$ tabel Pearson untuk signifikansi 0,05 dan dengan uji 2 sisi untuk $\mathrm{N}$ sebanyak 30 adalah 0.36 . Terlihat jelas bahwa tidak ada satupun nilai $r$ hitung dari semua item yang lebih rendah dari 0.36 , artinya $\mathrm{r}$ hitung $\geq \mathrm{r}$ tabel sehingga bisa dianggap valid untuk semua item di variabel tersebut.

\section{Uji Reliabilitas}

Arikunto (2013) mengatakan bahwa reliabilitas adalah suatu instrumen yang sudah baik yang cukup dapat dipercaya untuk digunakan sebagai pengumpulan data dan dapat diandalkan untuk melanjutkan ke tahap selanjutnya (Arikunto, 2013). Hasil data 
penelitian dapat dilihat pada tabel 2

di bawah ini.

Tabel 2

Hasil Uji Reabilitas

\begin{tabular}{|c|c|c|c|}
\hline Variabel & $\begin{array}{l}\text { Cronb ach } \\
\text { Alpha }\end{array}$ & $\begin{array}{c}\text { Cronbac } h \text { alpha yg } \\
\text { disyarat kan }\end{array}$ & $\begin{array}{l}\text { Kesim } \\
\text { pulan }\end{array}$ \\
\hline $\begin{array}{l}\text { Leadershi p Style } \\
\text { (X1) }\end{array}$ & 0,845 & $>0,600$ & Reliabe 1 \\
\hline $\begin{array}{l}\text { Organizati onal Culture } \\
\text { (X2) }\end{array}$ & 0,762 & $>0,600$ & Reliabe 1 \\
\hline $\begin{array}{c}\text { Productivi ty of Employee } \\
\text { (Y) }\end{array}$ & 0,868 & $>0,600$ & Reliabe 1 \\
\hline
\end{tabular}

Sumber: Hasil Olah Data (2018)

\section{Uji Asumsi Klasik}

a. Uji Normalitas

Pengujian

asumsi

normalitas untuk menguji data

variabel bebas $(\mathrm{X})$ dan variabel terikat (Y) pada persamaan regresi yang dihasilkan, apakah berdistribusi normal atau berdistribusi tidak normal

\section{Tabel 3}

Hasil Uji Normalitas

\begin{tabular}{|c|c|c|}
\hline & \multicolumn{2}{|c|}{$\begin{array}{l}\text { Unstandardized } \\
\text { Resiual }\end{array}$} \\
\hline \multicolumn{2}{|l|}{$\mathrm{N}$} & 30 \\
\hline \multirow{2}{*}{$\begin{array}{l}\text { Normal } \\
\text { Paramete rsa }\end{array}$} & Mean & .0000000 \\
\hline & Std. Deviation & 2.89345804 \\
\hline \multirow{3}{*}{$\begin{array}{l}\text { Most } \\
\text { Extreme Differenc es }\end{array}$} & Absolute & .095 \\
\hline & Positive & .084 \\
\hline & Negative & -.095 \\
\hline \multicolumn{2}{|l|}{ Kolmogorov-Smirnov Z } & .523 \\
\hline \multicolumn{2}{|l|}{ Asymp. Sig. (2-tailed) } & .947 \\
\hline
\end{tabular}

Hasil data tabel 3 menunjukkan bahwa pada kolom kolmogrovsmirnov dapat diketahui nilai signifikansi (Asyump.sig 2 tailed) yaitu sebesar 0,947. Nilai signifikansinya lebih besar dari 0,05 $(0,947>0,05)$ maka nilai residual tersebut adalah normal.

One-Sample Kolmogorov-Smirnov Test Normal P-P Plot of Regression Standardized Residual

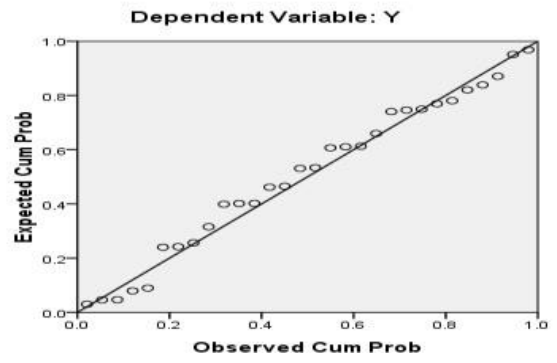


Hasil grafik P-Plot dari residualnya, terlihat titik atau data yang menyebar di sekitar garis diagonal dan mengikuti arah garis diagonal. Dengan demikian dapat disimpulkan bahwa model regresi memenuhi asumsi normalitas.

\section{b. Uji Multikolinearitas}

(Arikunto, 2013) adalah suatu hubungan liniear yang sempurna (mendekati sempurna) antara beberapa atau semua variabel bebas.

\section{Tabel 4}

Hasil Uji Multikolineritas

\begin{tabular}{|c|c|c|c|c|c|c|c|}
\hline \multirow{2}{*}{ Model } & \multicolumn{2}{|c|}{$\begin{array}{c}\text { Unstandardize d } \\
\text { Coefficients }\end{array}$} & \multirow{2}{*}{$\begin{array}{c}\begin{array}{c}\text { Standa rdized } \\
\text { Coefficients }\end{array} \\
\text { Beta }\end{array}$} & \multirow{2}{*}{$\mathbf{T}$} & \multirow{2}{*}{ Sig. } & \multicolumn{2}{|c|}{$\begin{array}{c}\text { Collinearity } \\
\text { Statistics } \\
\end{array}$} \\
\hline & B & $\begin{array}{l}\text { Std. } \\
\text { Error }\end{array}$ & & & & Tolerance & VIF \\
\hline (Const ant) & 18.862 & 5.252 & & 3.592 & .001 & & \\
\hline$\underline{X 1}$ & .325 & .158 & .327 & 2.055 & .050 & .621 & 1.611 \\
\hline $\mathrm{X} 2$ & .827 & .258 & .511 & 3.208 & .003 & .621 & 1.611 \\
\hline
\end{tabular}

Hasil 4 menujukkan bahwa nilai tolerance $\mathrm{X} 1$ dan $\mathrm{X} 2$ lebih besar dari 0,10 $(0,621>0,10)$, dan nilai VIF X1 X2 lebih kecil dari 10 (1.611 < 10). Sehingga bisa disimpulkan bahwa model regresi ini bebas dari multikolinearitas.

c. Uji Autokorelasi

$\begin{array}{lrr}\text { Imam } & \text { Ghozali } & \text { (2016) } \\ \text { mengatakan } & \text { bahwa } & \text { uji } \\ \text { autokorelasi } & \text { bertujuan } & \text { untuk } \\ \text { menguji apakah dalam } & \text { model } \\ \text { regresi linear ada korelasi antara }\end{array}$

Tabel 5

Hasil Uji Autokorelasi Model Summaryb

\begin{tabular}{lccccc}
\hline Model & R & R Square & $\begin{array}{c}\text { Adjusted } \\
\text { R Square }\end{array}$ & $\begin{array}{c}\text { Std. Error of the } \\
\text { Estim ate }\end{array}$ & $\begin{array}{c}\text { Durbin- } \\
\text { Watson }\end{array}$ \\
\hline 1 & $.758 \mathrm{a}$ & .575 & .543 & 2.999 & 1.790 \\
\hline
\end{tabular}

a. Predictors: (Constant), Organizational Culture, Leadership Style

b. Dependent Variable: Productivity of Employee

c. Predictors: (Constant), Organizational Culture, Leadership Style

d. Dependent Variable: Productivity of Employee

Sumber : Hasil Olah Data (2018) 
Hasil perhitungan pada tabel di atas menunjukkan bahwa nilai Durbin-Watson (DW) sebesar 1,790. Nilai DW lebih besar dari batas atas yaitu 1, nilai DW lebih kecil dari 2,4334. Nilai $\mathrm{DW}=$ $1,790>1,5666$ dan $1,790<$ 2,4334 maka tidak ada autokorelasi.

\section{d. Uji Heteroskedastisitas}

Uji heteroskedastisitas menurut Ce Gunawan (2018) digunakan utuk menguji apakah dalam model regresi terjadi ketidaksamaan varian dari residual satu pengamatan ke pengamatan yang lain (Gunawan, 2018).

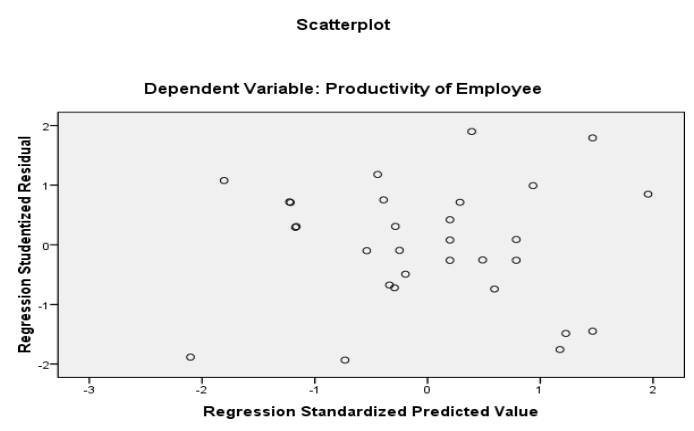

\section{Gambar 3 \\ Hasil Uji Heteroskedastisitas \\ Sumber: Hasil Olah Data (2018)}

Hasil output gambar scatterplot di atas, didapat titik menyebar di bawah serta di atas sumbu Y, dan tidak mempunyai pola yang teratur. Maka dapat disimpulakan variabel bebas dari model regresi di atas baik atau disebut homoskedastisitas dan tidak terjadi heteroskedastisitas.

\section{Pengujian Hipotesis}

\section{a. Uji Regresi Linear Berganda}

Pada penelitian ini, peneliti menggunakan analisis linear berganda karena ingin melihat pengaruh dari Leadership Style dan Organizational Culture terhadap Productivity of Employee di Koperasi Simpan Pinjam Sejahtera Bersama (KSP-SB) Cabang Sukabumi.

Tabel 6

Analisis Regresi Linier Berganda

Coefficientsa

\begin{tabular}{|c|c|c|c|c|c|c|}
\hline & \multirow{2}{*}{ Model } & \multicolumn{2}{|c|}{$\begin{array}{c}\text { Unstandardize d } \\
\text { Coefficients }\end{array}$} & \multirow{2}{*}{$\begin{array}{c}\begin{array}{c}\text { Stan dard ized } \\
\text { Coef ficie nts }\end{array} \\
\text { Beta }\end{array}$} & \multirow{2}{*}{$\mathbf{T}$} & \multirow{2}{*}{ Sig. } \\
\hline & & B & $\begin{array}{l}\text { Std. } \\
\text { Error }\end{array}$ & & & \\
\hline \multirow[t]{3}{*}{1} & (Const ant) & 18.862 & 5.252 & & 3.592 & .001 \\
\hline & Leader ship Style & .325 & .158 & .327 & 2.055 & .050 \\
\hline & $\begin{array}{l}\text { Organi zationa } 1 \\
\text { Culture }\end{array}$ & .827 & .258 & .511 & 3.208 & .003 \\
\hline
\end{tabular}

a. Dependent Variable:

Productivity of Employee

Sumber: Hasil Olah Data (2018)
Hasil analisis dengan menggunakan program SPSS 16 hasil persamaan regresi berganda for Windows di atas diperoleh sebagai berikut: $\mathrm{Y}=18,862+$ $0,325 \mathrm{X} 1+0,827 \mathrm{X} 2$. Persamaan 
regresi tersebut mempunyai makna sebagai berikut:

1) Konstanta $=18,862$

Jika variabel

Leadership Style dan

Organizational Culture sama dengan nol, maka variabel Productivity of Employee sebesar 18,826.

2) Koefisien $X 1=0,325$

Jika variabel

Leadership Style mengalami kenaikan sebesar satu satuan, sementara Organizational Culture dianggap tetap, maka akan menyebabkan kenaikan productivity sebesar 0.325 .

3) Koefisien $X 2=0,827$

Jika variabel Organizational Culture mengalami kenaikan sebesar satu satuan, sementara Leadership Style dianggap tetap, maka akan menyebabkan kenaikan productivity sebesar 0,827 .

\section{Tabel 7}

Hasil Uji Koefisien Determinasi

\begin{tabular}{lrrrrr}
\hline \multicolumn{5}{c}{ Mode Summaryb } \\
\hline Model & R & R Square & $\begin{array}{c}\text { Adjusted R } \\
\text { Square }\end{array}$ & $\begin{array}{c}\text { Std. Error of } \\
\text { the Estimate }\end{array}$ \\
\hline 1 & $.758 \mathrm{a}$ & .575 & .543 & 2.999
\end{tabular}

a. Predictors: (Constant), Organizational Culture, Leadership Style

b. Dependent Variable: Productivity of Employee

Sumber: Hasil Olah Data (2018)

Tabel 7 menunjukkan perolehan nilai Adjusted $\mathrm{R}$ Square (R2) sebesar 0,543= $54,3 \%$, maka dapat disimpulkan bahwa variabel Leadership Style dan Organizational Culture secara bersama-sama memengaruhi variabel Productivity of Employee sebesar 54,3\%, sedangkan sisanya sebesar $45,7 \%$ dipengaruhi oleh faktor lain yang tidak digunakan dalam penelitian ini.

\section{b. Uji t (Uji Parsial)}

Imam Ghozali

(2016) mengatakan bahwa uji $t$ digunakan untuk menunjukkan seberapa jauh pengaruh satu variabel penjelas/independen secara individual dalam menerangkan variasi variabel dependen (Ghozali, 2016).

Tabel 8

Analisis Uji t (Parsial)

\begin{tabular}{llrrrrr}
\hline 1 & (Const ant) & 18.862 & 5.252 & & 3.592 & .001 \\
\hline & Leader ship Style & .325 & .158 & .327 & 2.055 & .050 \\
\hline & Organi zationa 1 Culture & .827 & .258 & .511 & 3.208 & .003 \\
\hline
\end{tabular}

a. Dependent Variable: Productivity of

Sumber : Hasil Olah Data (2018) 
Style (X1) memiliki nilai $\mathrm{t}$ hitung sebesar 2,055, pada analisis regresi digunakan probabilitas 2 sisi untuk mengetahui nilai t tabel, distribusi t dicari pada $\mathrm{a}=5 \%: 2=2,5 \%$ (uji 2 sisi) dengan derajat kebebasan (df) n-k atau 30-3 = 27 (n adalah jumlah kurun waktu pada observasi dan $\mathrm{k}$ adalah jumlah variabel), dengan pengujian 2 sisi ( signifikansi $=0,025)$ maka diperoleh hasil untuk tabel yaitu sebesar 2,05183. Nilai t hitung variabel Leadership Style (X1) lebih besar dari nilai t tabel $(2,055$ $>$ 2,05183) dengan tingkat signifikan setara dengan 0,05 yaitu sebesar $0,050(0,050=0,05)$ maka Ho ditolak dan Ha diterima. Nilai $t$ hitung variabel Organization Culture (X2) lebih besar dari pada nilai t tabel $(3,208$ $>$ 2,05183) dengan tingkat signifikan di bawah 0,05 yaitu 0,003, maka Ho ditolak dan Ha diterima. Cara pengambilan keputusan uji parsial dalam analisis regresi dapat disimpulkan sebagai berikut:

1) Variabel Leadership Style (X1) secara parsial berpengaruh positif namun tidak signifikan terhadap variabel $\mathrm{Y}$ (Produktivity of Employee).

2) Variabel Organizational Culture (X2) secara parsial berpengaruh positif dan signifikan terhadap variable $\mathrm{Y}$ (Produktivity of Employee).

c. Uji F (Uji Simultan)

Imam Ghozali (2016) mengatakan bahwa uji $F$ digunakan untuk mengetahui variabel independen (X1, X2, ..., $\mathrm{Xn}$ ) secara bersama-sama berpengaruh secara signifikan terhadap variabel dependen (Y). Sebuah model dikatakan baik jika nilai $\mathrm{F}$ menunjukkan signifikan. Nilai F signifikan jika signifikansinya lebih kecil dari 0,05 .

\section{Tabel 9}

Uji F (Uji Simultan)

ANOVAb

\begin{tabular}{|c|c|c|c|c|c|c|}
\hline & Model & $\begin{array}{c}\text { Sum of } \\
\text { Squares }\end{array}$ & Df & $\begin{array}{c}\text { Mean } \\
\text { Square }\end{array}$ & $\mathbf{F}$ & Sig. \\
\hline \multirow[t]{3}{*}{1} & Regression & 327.909 & 2 & 163.955 & \multirow{3}{*}{18.233} & \multirow{3}{*}{$.000 \mathrm{a}$} \\
\hline & Residual & 242.791 & 27 & 8.992 & & \\
\hline & Total & 570.700 & 29 & & & \\
\hline
\end{tabular}

a. Predictors: (Constant), Organizational Culture, Leadership Style

b. Dependent Variable: Productivity of Employee

Sumber: Hasil Olah Data (2018) 
Hasil output SPSS pada tabel Anova di atas menunjukkan bahwa variabel Leadership Style dan Organizational Culture memiliki nilai $\mathrm{F}$ hitung yaitu sebesar 18,233 dengan nilai signifikan 0,000. Nilai f-tabel dapat dicari dengan menggunakan tingkat kepercayaan $5 \%$ atau 0,05 dan dengan nilai df2 maka diperoleh nilai $F$ tabel sebesar 3,35. Kriteria penerimaan hipotesis yaitu Ho ditolak dan $\mathrm{Ha}$ diterima apabila nilai signifikansi kurang dari taraf kesalahan 5\% $(0,05)$ dan nilai $\mathrm{F}$ hitung $>\mathrm{F}$ tabel. Nilai signifikan pada variabel Leadership Style dan Organizational Culture kurang dari $5 \%$ atau 0,05 yaitu sebesar
0,000 dan nilai $F$ hitung lebih besar dari $\mathrm{F}$ tabel $(18,233>3,35)$ sehingga dapat disimpulkan bahwa Leadership Style dan Organizational Culture secara simultan berpengaruh positif dan signifikan terhadap Productivity of Employee.

\section{d. Analisis Korelasi}

Ce Gunawan menjelaskan bahwa Analisis korelasi digunakan untuk mengetahui keeratan hubungan antara dua variabel dan untuk mengetahui arah hubungan yang terjadi antara dua variable (Gunawan, 2018). Berikut tabel 10 menujukkan hasil analisis korelasi.

Tabel 10

Analisis Korelasi Correlations

\begin{tabular}{|c|c|c|c|c|}
\hline & & $\begin{array}{c}\text { Leadership } \\
\text { Style }\end{array}$ & $\begin{array}{l}\text { Organizational } \\
\text { Culture }\end{array}$ & $\begin{array}{c}\text { Productivity of } \\
\text { Employee }\end{array}$ \\
\hline \multirow[t]{3}{*}{ Leaders hip Style } & $\begin{array}{l}\text { Pearson } \\
\text { Correlation }\end{array}$ & 1 & $.616^{* *}$ & $.642^{* *}$ \\
\hline & Sig. (2-tailed) & & .000 & .000 \\
\hline & $\mathrm{N}$ & 30 & 30 & 30 \\
\hline \multirow[t]{3}{*}{$\begin{array}{l}\text { Organiz ational } \\
\text { Culture }\end{array}$} & $\begin{array}{l}\text { Pearson } \\
\text { Correlation }\end{array}$ & $.616^{* *}$ & 1 & $.713^{* *}$ \\
\hline & Sig. (2-tailed) & .000 & & .000 \\
\hline & $\mathrm{N}$ & 30 & 30 & 30 \\
\hline \multirow[t]{3}{*}{$\begin{array}{l}\text { Producti vity of } \\
\text { Employ ee }\end{array}$} & $\begin{array}{l}\text { Pearson } \\
\text { Correlation }\end{array}$ & $.642^{* *}$ & $.713^{* *}$ & 1 \\
\hline & Sig. (2-tailed) & .000 & .000 & \\
\hline & $\mathrm{N}$ & 30 & 30 & 30 \\
\hline
\end{tabular}

**. Correlation is significant at the 0.01 level (2-tailed).

Sumber: Hasil Olah Data (2018)

Hasil output spss di atas, berdasarkan nilai signifikansi diketahui bahwa antara Leadership Style (X1), dengan Organizational Culture (X2), memiliki nilai signifikansi $0,000<$
0,05 , yang artinya terdapat korelasi yang signifikan. Selanjutnya, antara Leadership Style (X1) dengan Productivity of Employee (Y) nilai signifikansinya $0,000<0,05$, yang 
artinya terdapat korelasi yang signifikan. Terakhir, antara Organizational Culture (X2) dengan Productivity of Employee (Y) memiliki nilai signifikansi $0,000<0,05$, yang artinya kedua variabel tersebut terdapat korelasi yang signifikan.

\section{B. Pembahasan}

\section{Pengaruh Leadership Style terhadap Productivity of Employee}

Penelitian yang dilakukan oleh peneliti di KSP-SB cabang Sukabumi menunjukkan hasil bahwa pemimpin yang mempunyai Leadership Style yang tepat akan berbuah baik dan optimal. Kreitner (2009) mengemukakan bahwa Leadership Style akan berdampak pada productivity maupun perusahaan sehingga perusahaan dapat menghasilkan output yang tinggi dan mencapai tujuan yang telah ditetapkan (Kreitner, 2010). Pernyataan tersebut didukung oleh hasil regresi yang menunjukkan adanya pengaruh Leadership Style terhadap Productivity of Employee. Hasil penelitian ini sama dengan penelitian yang telah dilakukan oleh beberapa peneliti sebelumnya diantaranya; (Setiawan, 2010) "Pengaruh Gaya Kepemimpinan dan Budaya Organisasi Terhadap Produktivitas Kerja Pegawai Dinas Olahraga Dan Pemuda Provinsi Jawa Barat", Minarti Luhat, "Pengaruh Gaya Kepemimpinan Dan Komunikasi Terhadap Produktivitas Kerja Karyawan Pada PT Gunta Semba Jaya Miau Baru Estate Di Desa Miau Baru', (Latief, 2015)
"Pengaruh Gaya Kepemimpinan Dan Motivasi Terhadap Produktivitas Kerja Karyawan Pada Afdeling Prapen I Kebun Unit 1 Pt Monopoli Raya Kabupaten Langkat', (Zebua, 2017) "Pengaruh Gaya Kepemimpinan Terhadap Produktivitas.

Kerja Karyawan Pad Apt Coca-Cola Cabang Malang”, dan (Goren, 2018) “The Effect Of Leadership Styles On Employee Productivity At South Nyanza Sugar Company Limited, Migori County”, yang menyatakan bahwa Leadership Style berpengaruh positif dan signifikan terhadap productivity of employee.

2. Pengaruh Organizational Culture terhadap Productivity of Employee

Penelitian yang dilakukan oleh peneliti di KSP-SB cabang Sukabumi menunjukkan hasil bahwa penerapan Organizational Culture yang baik akan mencerminkan diri sendiri dan saling bekerja sama dalam tim akan menghasilkan productivity yang sesuai. (Wirawan, 2011) mengatakan bahwa Organizational Culture akan berdampak pada productivity maupun perusahaan sehingga perusahaan dapat menghasilkan output yang tinggi dan mencapai tujuan yang telah ditetapkan (Wirawan, 2011). Pernyataan tersebut didukung oleh hasil regresi yang menunjukkan adanya pengaruh Organizational Culture terhadap Productivity of Employee. Hasil penelitian ini selaras dengan penelitian yang telah dilakukan oleh beberapa peneliti sebelumnya diantaranya; (Setiawan, 2010) 
"Pengaruh Gaya Kepemimpinan dan Budaya Organisasi Terhadap Produktivitas Kerja Pegawai Dinas Olahraga Dan Pemuda Provinsi Jawa Barat", dan (Ahiabor, 2014) "The Impact Of Corporate Culture On Productivity Of Firms Ini Ghana: A Case Of Vodafone Ghana”, yang menyatakan bahwa Organizational Culture berpengaruh positif dan signifikan terhadap Productivity of Employee.

\section{Pengaruh Leadership Style dan} Organizational Culture secara simultan terhadap Productivity of Employee

Hasil penelitian yang telah dijelaskan di atas dapat disimpulkan bahwa Leadership Style dan Organizational Culture secara simultan mampu memengaruhi Productivity of Employee. Hasil tersebut didukung oleh penyataan Paul Mali dalam (Setiawan, 2010) bahwa productivity of employee merupakan sinergi dari semua faktor yang terbentuk pada empat level yaitu dua diantaranya Leadership Style dan organizational culture. Hasil uji $F$ menunjukkan bahwa kedua variabel independen secara simultan berpengaruh terhadap Productivity of Employee. Hasil penelitian ini selaras dengan penelitian yang dilakukan oleh (Setiawan, 2010) "Pengaruh Gaya Kepemimpinan dan Budaya Organisasi Terhadap Produktivitas Kerja Pegawai Dinas Olahraga Dan Pemuda Provinsi Jawa Barat', yang menemukan bahwa Leadership Style dan Organizational Culture secara simultan berpengaruh positif terhadap productivity of employee secara signifikan, dengan demikian maka dapat disimpulkan bahwa hipotesis ketiga (Ha-3) diterima.

\section{Simpulan}

Berdasarkan hasil penelitian dan olah data mengenai pengaruh Leadership Style dan Organizational Culture terhadap productivity of employee di Koperasi Simpan Pinjam-Sejahtera Bersama (KSPSB) Cabang Sukabumi, maka dapat diperoleh beberapa kesimpulan antara lain sebagai berikut:

1. Hasil penelitian di atas menunjukkan bahwa terdapat pengaruh positif namun tidak signifikan antara Leadership Style terhadap Productivity of Employee di KSP-SB di Cabang Sukabumi. Hal ini menunjukkan bahwa semakin tepat dan bagus penerapan leadership style, maka Productivity of Employee akan semakin meningkat dalam menghasilkan output productivity-nya.

2. Hasil penelitian di atas menunjukkan bahwa terdapat pengaruh positif dan signifikan antara Organizational Culture terhadap Productivity of Employee di KSP- SB Cabang Sukabumi. Hal ini menujukkan bahwa semakin diterapkan dengan baik organizational culture, maka Productivity of Employee akan semakin meningkat dalam menghasilkan output productivity-nya.

3. Hasil penelitian di atas menunjukkan bahwa terdapat pengaruh yang signifikan antara Leadership Style dan Organizational Culture secara simultan terhadap Productivity of Employee di KSP-SB Cabang Sukabumi. Hal ini menunjukkan bahwa semakin baik dan tepat penerapan Leadership Style dan organizational culture semakin 
diterapkan lagi oleh para karyawan, maka Productivity of Employee di Koperasi Simpan Pinjam-Sejahtera Bersama (KSPSB) Cabang Sukabumi pun akan semakin meningkat.

4. Hasil penelitian di atas menunjukkan bahwa antara Leadership Style (X1) dengan Organizational Culture (X2), memiliki korelasi yang signifikan.

Selanjutnya, antara Leadership Style (X1) dengan Productivity of Employee (Y) memiliki korelasi yang signifikan. Terakhir, antara Organizational Culture (X2) dengan Productivity of Employee (Y), kedua variabel tersebut terdapat korelasi yang signifikan.

\section{Saran}

Berdasarkan hasil penelitian yang telah diperoleh, maka penulis membagi saran menjadi 2 (dua) jenis, yaitu:

1. Saran Teoritis

a. Bagi yang hendak melakukan penelitian tentang MSDM, diharapkan dapat melakukan kajiannya dari permasalahan dan sudut pandang yang berbeda atau menggunakan variabel penelitian yang berbeda, sehingga akan menambah dan memperluas khasanah teoritis akademis dalam pembelajaran ilmu manajemen khususnya di bidang MSDM.

b. Bagi peneliti selanjutnya yang akan melakukan penelitian di Koperasi Simpan Pinjam-Sejahtera Bersama (KSP- SB) Cabang Sukabumi, diharapkan untuk lebih memperkaya bukti empiris, hal tersebut akan menambah informasi, kebenaran dan kepercayaan dari judul yang diteliti.
2. Saran Praktis

a. Bagi Leadership KSP-SB Cabang Sukabumi, sebaiknya tingkat komunikasi antara atasan dengan bawahan lebih ditingkatkan lagi pada masa yang akan datang, yaitu dengan cara pimpinan dengan bawahan harus saling berinteraksi dengan baik demi meningkatkan productivity dan menghasilkan output yang tinggi.

Pemimpin harus mencari atau mengubah Leadership Style menjadi lebih tepat untuk para karyawannya. Pimpinan juga harus sering melatih leader dari masing-masing tim agar para karyawan bisa lebih terarah dan terlatih dalam melaksanakan pekerjaannya. Pimpinan diperusahaan sebaiknya harus lebih bisa memotivasi karyawannya dengan lebih baik lagi. Penurunan productivity bisa jadi karna ada faktor lain dari kepemimpinan yang mempengaruhi Productivity of Employee, misalnya lebih sering memberikan apresiasi berupa bonus atau upah, 2-3 bulan sekali melakukan refreshing agar para karyawan tidak merasakan jenuh karna bekerja setiap hari ketika ada di kantor.

b. Bagi Organizational Culture yang terdapat pada KSP-SB Cabang Sukabumi, bahwa indikator yang menunjukkan Organizational Culture dan pengaruhnya terhadap Productivity of Employee yaitu kerja sama dalam tim dan loyalitas dalam tim bisa dikatakan kurang. Perusahaan akan mengalami kesuksesan jika terdapat SDM yang baik, dimana SDM tersebut merupakan modal utama dalam 
kesuksesan suatu perusahaan. kerja sama dalam tim dan loyalitas tim merupakan hal penting yang harus dimiliki oleh seorang karyawan, jadi kerja sama dan loyalitas dalam tim di Koperasi Simpan Pinjam-Sejahtera Bersama (KSP-SB) Cabang Sukabumi harus lebih dieratkan dan ditingkatkan lagi, agar dapat menghasilkan output yang tinggi dalam Productivity of Employee nya.

c. Bagi manajemen KSP-SB Cabang Sukabumi diharapkan sebaiknya bisa lebih mensosialisasikan koperasi kepada masyarakat banyak dan mendapatkan karyawan lebih banyak untuk bagian sales atau finance advisor, sehingga para karyawan pada bagian tersebut lebih gampang untuk meraup nasabah lebih banyak dan akan menjadi keuntungan bagi income perusahaan.

\section{Daftar Pustaka}

Adinata, W. S. U. (2015). Pengaruh Kepemimpinan Transformasional, Motivasi, dan Budaya Organisasi terhadap produktivitas kerja KJKS BMT TAMZIS Bandung. Jurnal Ekonomi, Bisnis\&Entrepreneurship Oktober. ISSN 2443-2121, Vol.9, No.

Ahiabor, G. (2014). The Impact Of Corporate Culture On Productivity of Firms In Ghana: A Case Of Vodafone Ghana.

Arikunto, S. (2013). Prosedur Penelitian Suatu Pendekatan Praktik. Rineka Cipta.

Badrudin. (2013). Dasar-Dasar Manajemen.
Alfabeta.

Blanchard, H. (1996). Kuesioner Gaya Kepemimpinan. Academia.Edu. http://www.academia.edu/24290374/K uesioner_Gaya_Kepemimpinan_Model _Hersey_And_B1\%0Aanchard_

Ghozali, I. (2016). Aplikasi Analisis Multivariate dengan Program IBM SPSS 23. Badan Penerbit Universitas Diponegoro.

Goren, P. (2018). Effect of Leadership Styles on Employee Productivity at South Nyanza Sugar Company Limited, Migori County. International Journal of Progressive Sciences and Technologies, Vol 6 No 2.

Gunawan, C. (2018). Mahir Menguasai SPSS (Mudah Mengolah Data Dengan IBM SPSS Statistic 25). Cetakan Ke-1. Deepublish.

Handoko, T. H. (2014). Personnel and Human Resources Management. BPFE.

Hasibuan, M. S. . (2013). Manajemen Sumber Daya Manusia, cetakan ke-21. Bumi Aksara.

Indrajaya; I. G. A. A. dan I. G. A. D. A. (2013). Pengaruh Budaya Organisasi, Komunikasi Dan Lingkungan Kerja Terhadap Produktivitas Kerja Karyawan Cv. Hitakara Denpasar. Jurnal Manajemen, Vol 2 No 4.

Kartono. (2017). Pengaruh Gaya Kepemimpinan Dan Budaya Organisasi Terhadap produktivitas Melalui Kepuasan Kerja Karyawan.

Kreitner, R. A. K. (2010). Organizational Behavior. McGraw Hill.

Laporan Tahunan Dana Anggota Simpanan Untuk Remunerasi Tahun 2014 - 2017. (2017). 
Latief, A. (2015). Pengaruh Gaya Kepemimpinan dan Motivasi terhadap Produktivitas Kerja Karyawan pada Afdeling Prapen I Kebun Unit 1 PT Mopoli Raya Kabupaten Langkat. Jurnal Manajemen Dan Keuangan, Vol 4 No 1.

Luhat, M. (2017). No Title pengaruh Gaya Kepemimpinan Dan Komunikasi Terhadap Produktivitas Kerja Karyawan Pada Pt. Gunta Samba Jaya Miau Baru Estate Di Desa Miau Baru. Program Studi Ilmu Administrasi Bisnis.

Mangkunegara, A. A. P. (2013). Manajemen Sumber Daya Manusia Perusahaan. Remaja Rosdakarya.

Nasution, M. N. (2004). Manajemen Mutu Terpadu (Total Quality Management). Cetakan ke-3. Ghalia Indonesia.

Ongi, A. (2015). Pengaruh Budaya Organisasi Dan Motivasi Kerja Terhadap Produktivitas Karyawan Pada PT. Nusa Halmahera Minerals Di Kab. Halmahera Utara. Jurnal Administrasi Publik.

Rahmawati, H. (2016). Pengaruh Nilai Kerja Terhadap Produktivitas Kerja Karyawan Produksi.

Robbins, P. S. T. A. J. (2012). Perilaku Organisasi. Salemba Empat.

Setiawan, Y. (2010). Pengaruh Gaya Kepemimpinan Dan Budaya Organisasi Terhadap Produktivitas Kerja Pegawai Dinas Olah Raga Dan Pemuda Provinsi Jawa Barat. Jurnal Manajemen Dan Sistem Informasi, Vol 9, No.

Sweeney, P.D., dan McFarlin, D. . (2002). Organizational Behaviour: Solution for Management. McGraw Hill.
Thoha, M. (2007). Kepemimpinan dalam Manajemen, Edisi 12. PT. Raja Grafindo Persada.

Wirawan. (2011). Evaluasi Teori Model Standar Aplikasi dan Profesi, Contoh Aplikasi Evaluasi Program: Pengembangan Sumber Daya Manusia, Program Nasional Pemberdayaan Masyarakat (PNPM) Mandiri Pedesaan, Kurikulum, Perpustakaan, dan Buku Tes. Raja Grafindo Persada.

Zebua, M. (2017). Pengaruh Gaya Kepemimpinan Terhadap Produktivitas Kerja Karyawan Pada Pt. Coca-Cola Cabang Malang. Media Mahardhika Vol. 15 No. 3 Mei 2017. 